ドを表わす成分とに分かれる，3）正常な部位と微少な wash out delay の部位の重なっている場合には，3つの 因子に分かれ wash out delay を指摘できる。 と述べた。 factor analysisは，処理してできあがったカーブや画像 がなにを示すかをよく考えながら結論づけなければなら ない所に特徴がある．より検討を加えてこの方法の有用 性や限界がより明らかになることを望む。

演題151は，“C-glucose の肺腫瘍診断にお计る有用性 に関する発表であった。 ${ }^{67} \mathrm{Ga}$-citrateによるシンチグラ フィーもあわせて行い比較されていた，しかじC. glucoseによる画像は, ${ }^{67} \mathrm{Ga}$-citrate による画像よりもバ ックグランドが強くわるかった。そのおもな原因は，コ リメータにあるということであった。ポジトロン核種は, 医学的に興味のあるところであるが，技術的な側面から の検討もどんどん期待したいものである。

\section{MRI-1 撮影技術}

座長 五鼠仁士（東芝中央病院）

152. プロトン用表面コイルの評価一体部用コイル・頭部 用コイルとの比較一

国立循環器病センター放射線診療部

○山田幸典・佐久間英治・内田英治

坂下善治・覓組一男

プロトン用表面コイル 2 種 (spine $16 \mathrm{~cm} \phi$, orbit 11 $\mathrm{cm} \phi)$ をbody, head coil と比較した。表面コイル 2 種 の深さ方向の信号強度は, 既知のようにコイル径小の方 がコイル近くの感度は高いが深さに伴う減衰は大きい。 slice 厚または averageを增加すると $\mathrm{S} / \mathrm{N}$ 比は增加す る.TR0.5sec, slice 厚 $10 \mathrm{~mm}, \mathrm{AV} 2$ 回における $\mathrm{S} / \mathrm{N}$ 比は head 123 , spine 120 , orbit 114 , body 83.3 であっ た。感度は表面より $4 \mathrm{~cm}$ の点で orbit 4.20 , head 3.31 , spine 2.74, body1.03であった. 空間分解能はコイルの種 類, slice 厚，AVには関係せず Matrix 128，128 R で 2 . $5 \mathrm{~mm}, 256,256 \mathrm{R}$ で $1.5 \mathrm{~mm}$ であった。総合解像力は S/ N比も含め評価できる低コントラストファントムが必 要であろう。

\section{3. サーフェスコイルの有用性}

$$
\begin{aligned}
& \text { 千葉大学放射線部 } \\
& \text { ○梁川範幸・今井博久 } \\
& \text { 守田文範・植松貞夫 } \\
& \text { 千葉大学放技校 } \\
& \text { 山本哲夫・田中 仁 }
\end{aligned}
$$

頸部用サーフェスコイルを使用するにあたり，比較用 としてボディコイルを使用してその基礎的実験を行った。
サーフェスコイルは受信感度が良く average 数を減ら すことができ撮像時間を短縮できる利点がある.FOV内 での均一性はボディに比べサーフェスの方が著しく不均 一で，特に深さ方向では撮像範囲が狭くなることがわか つた。 中心部付近での解像力の比較はサーフェスの方が 传れていた。これは局所的な部位を観るのに役立つた。 また 、值は中心部付近で両者ともほとんど一致した。 臨床例においてサーフェスでは spinal cordやその周り の組織が鮮明に表うれていた。頚部用サーフェスコイル の使用は局所的な形態を知るためには有用であった。

154. NMR-CT における ECG および呼吸 GATE を用い た画質の改善

NTT厇島中央健康管理所

○岡村雅善・小田伸二・下中英二

山形俊之・森 康彦

〔目的〕MRI検查において，体動によるアーチファク 卜が診断の妨げになることがしばしばある。そこでわれ われはアーチファクト除去のため心電および呼吸同期を 用いて画質の改善を試みたので報告する。

[結果]心筋のscanにおいては非同期に比べ，心筋 の愿みをはっきり読み取ることができ，スライス面を変 えることにより弁疾患による心内腔の拡張，解離性大動 脈瘤などの診断も可能であった。呼吸同期においては， 肝藏の辺縁が同期をかけた場合，比較的よく読み取れ， 時間がかかりすぎるという問題点はあるが，呼吸同期が 有効であることがわかった。

\section{MRIにおける任意斜断面撮影の有用性}

自治医科大学附属病院中央放射線部

○杉山 修・ 中村琢也・神山辰彦 佐藤清明・寺門秀司・間瀬 博

自治医科大学附属病院では昭和 60 年 7 月より東芝製常 電導 MRI 装置 MRT-22A (0.22 T) を設置して臨床治娩 を行った. MRT-22A にはマルチスライスで撮影した平 行な 2 枚の画像から任意の断面を撮影する機能がある. この機能により以下の有用性が得られた。

1. 任意斜断面は基準画像より容易に得られる。

2，心臟，血管，骨等体軸に平行あるいは直交してい ない部位も容易に同一面上に撮影することができる。

3. 病変と主要臟器との関係をより立体的にとらえら れる。

4.新たな基準を決めることにより㛟査の幅を広げる ことができる。

156. MRIにおける心診断用撮像面の設定方法の考察 株式会社島津製作所 